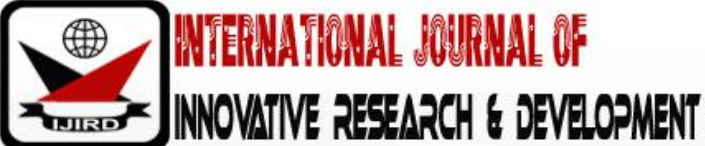

ISSN 2278 - 0211 (Online)

\section{Youths and National Development in Nigeria}

Oladepo Kazeem Adebowale
Senior Lecturer, Department of Local Government and Development
Studies, Polytechnic Ibadan, Oyo State, Nigeria
Salau Jelili Olawale
Senior Lecturer, Department of Political Science,
Micheal Otedola College of Education, Noforija, Epe, Lagos State, Nigeria

\section{Abstract:}

The role of youths in national development in Nigeria cannot be over emphasis; this is not unconnected with the fact that the wheel of development of any country squarely rest on the shoulder of how productivity and creativity the youthful populations are. The youth are the engine of growth and development since they provide the labour force for production of goods and service. They are critical masses of people whose action and inaction can develop or destroy the hegemonies of their society. This paper argues that a country that prepare her youth for the sake of future aspiration will not only secure her future development but will prepare her next set of leaders with the challenges of national reconciliation and development. With heavy reliance on secondary data derived from library search, archival records and internet search, this paper will present illuminating discourse on the role of youth in national development in Nigeria.

Keywords: Role, youth and national development

\section{Introduction}

Since the United Nation first decade of development (1960-1970), theoretical deconstruction of development discourse has created premises for the reconstruction of the human development paradigm. With these paradigmatic reconstruction, contemporary neoliberal development theorizing engenders discourses of inclusion, participation, and empowerment of youth population in the development of a country (Cornwall, 2010; Pieterse, 2010). Regardless of these strides and until recently, development theorizing and policy practice remained trapped in vertical dichotomous debates as it strove to balance between development realities and youth inclusion. Indeed, based on these narrow focus of human abstraction that ignore the specificities and transient horizontal realities across human life-course (childhood and youth), recent studies (Ismail et al, 2009; Wardany, 2012 and Arah 2013) have shown that youth are the cornerstone to societal rejuvenation and development.

To them, Societies are not only recreated through the youthful population, but, youth are often referring to as leaders of tomorrow. Their mindset and roles is of major important to the development of any society. According to the 2006 census in Nigeria, the youthful population constituted over $70 \%$ of the population. This quantum of population is great assets for the Nigerian state if harness and utilize in the right direction. No nation will experience development when the preponderance of the population that constitutes the largest percentage of the population are ineffective.In this regard, the youths, not oil are considered as a key of Nigeria national development.

Unfortunately, these projections, expectations, and future forecasts, seem to be an abysmal blindfolded future, if the prevailing realities in Nigeria is anything to go by. The current state of the mind of Nigerian youth is not encouraging and doesn't inspire confidence. Societal neglects and government inability to design an integrated and implementable policy framework targeting the youthful energy for national development, has left the youth without guardianship, mentorship and direction. This has led to the agonies of poverty, unemployment, frustration, despondences, confusion, hopelessness, parental and governmental neglects.

To this end, the ability of nations to rise and consolidate the gains of globalization, lies in training and educating well inform youths. In addition, the secret of development in Europe, Asia and other developed nations is the miracle of development of human engines through youth education and skill acquisition. Therefore, it is important, for policy makers, parents and other stake holders, to understand and appreciate that, if youth are to be the future of Nigeria, their mindset and creativity should be a major concern to the nation. 


\section{Conceptual Clarification}

The concept of youth has been defined by different scholars. The national youth development policy (2001) defines youth as people between ages 18-35 and that they constitute about $60 \%$ of more than 146 million people of Nigeria.

Stressing further, Onyekpe (2007) opined that youth occupy a prominent place in any society. According to him apart from being leaders of tomorrow, they outnumbered the middle-aged and the aged. Besides the numerical superiority as he puts it, youth have energy and ideas that can make a society great.

Yusuf (2001) sees youth as group of people that are neither adolescents nor children and characterized by excessive energy that need to be exerted which if not guarded, can be channeled into negative tendencies.

Sulaiman (2006) asserted that youth being the most active segment of any society, are major determiners of peace and stability of any nation.

To Okafor (2011) youth represents a very important stakeholder in any society. To him therefore, they are not only future of that society but also a major stakeholders and useful resources in the nation building.

Therefore sequel to the above definitions youth can be seen as body of people or person with great powers, energies and potentials but with little lives experiences.

\section{Development}

The conceptualization of development has undergone metamorphosis since the Second World War ended in 1945. The meaning and the conceptualization of development was greatly influenced by the ideological contradiction between the Socialist East and the Capitalist West.

To Stightz (2005), development is a process of transformation of society by which the members of a society increase their potential and institutional capacity to mobilize and manage resources for produce suitable and justify distributed improvements in their quality of life consistence with their own aspiration.

The above position confirmed the contribution of Sen (1999) that sees development as a multifarious concept that incorporate the fundamental component viz: improvement of people's living standard in income and consumption level of food, medical services education etc. through relevant growth processes and creation of conditions for the growth of the people's self esteem through the establishment of social, political and economic systems and institutions which promote human dignity and respect. It is clear from this perspective that more than anything, human beings are seen as the centre of development. Sen represents most probably the arrow head of direction in development discourse and introduced the 'capabilities' approach into debate on conceptualization of development while given a clear insight by asserting that 'development has to be more concerned with enhancing the lives that we lead and the freedom that we enjoy'.

Development to Dudley Seer (1977) can be viewed on the basis of human well being. For him, development does not mean only capital accumulation and economic growth but also the condition in which people in a country have adequate food and job and income inequality among them is greatly reduced. It is a process of bringing about fundamental and sustainable change in society. It encompasses what Lawal (2007) and Egharevba (2007) referred to as growth embraces such aspect of the 'quality of life as social justice equality for all citizens, equitable distribution of income and democratization of the development process.

It is therefore not surprise that Obansanjo and Mobogunje (1991) defined development as 'a process concerned with people's capacity in a defined area, over a defined period, to manage and induce change'. In actual fact, Obasanjo and Mabogunje unequivocally asserted that development is people inspired that development is people inspired, humancentered and citizens-anchored.

Corroborating Obasanjo and Mobogunje's conception of development, the United Nation Development Programmes (UNDP) (1988) position seems totally in line, when it viewed development in terms of transformation sustainability. That is holistic development paradigm that sees human being as both the means and the end of development. It seeks to expand choices for all people, current and future generation, while protecting the natural system on which all life depends.

\section{Youths and National Development in Nigeria}

Historically, the impasse about the Nigeria National development began through a philosophical and intellectual revolution in which youth were primary agent and western education model were tools in fostering the process of psychological development which would in turn translate to general development of Nigeria (Woolman, 2001). Through western education, youth nationalist movement reproduced the same ideological underpinning of colonial scheme (Olaiya, 2014) and used as an integral aspect in addressing nation building and development problems like integrating multicultural traditions and ethno-regional mandates; narrowing the gaps between rural livelihood; bridging the divides between ethnic and geographical access to resources and general development of the entire Nigeria (Abuduntu, 2010).

Unfortunately, these projections, expectations, and future forecasts, seem to be an abysmal blindfolded future, if the prevailing realities in Nigeria is anything to go by. The current state of the mind of Nigerian youth is not encouraging and doesn't inspire confidence. Societal neglects and government inability to design an integrated and implementable policy framework targeting the youthful energy for national development, has left the youth without guardianship, mentorship and direction. Instead of utilizing their energy, curiosity, creativity, passion and impatient for change to foster national development; unfortunately, the gamut of the Nigeria society has left the youth without hope, guardianship, mentorship and future aspiration resulting in the agonies of poverty, unemployment, frustration, despondences, confusion, hopelessness, parental and governmental neglect. 
According to national Bureau of statistics (2019), the national unemployment rate for Nigeria showed that the number of unemployed person constituted $19.58 \%$. Specifically as regard the age group, educational group and sex, the data provided by the National bureau of statistics (2019) further showed that as at March 2019 in Nigeria, for person between age 15 and 24 years, $41.6 \%$ were unemployed. For persons between $25-44$ years, $17 \%$ were unemployed. Also, those with primary education, $14.8 \%$ were unemployed and those with only Secondary, $23.8 \%$ were unemployed. Furthermore, for those with post secondary education 21:23 were unemployed. For those who never attended school and those with below primary education, $21.0 \%$ and $22.3 \%$ were unemployed respectively. As regards sex, the data showed that male constituted $17.0 \%$ while female constituted $23.3 \%$.

It is therefore important to note that the figures above may not have captured in totality, the youth unemployment situation in Nigeria, however, they are pointing to the fact that the phenomenon is a very critical issue with far-reaching implications for Nigeria.

Presently, Nigeria maintains a worrisome status of the global poverty with high prevalence rate of crimes and criminality, including mass murders, insurgency, militancy, armed robbery, kidnappings and drug abuse, among others. As if this situation is not scary enough, it is projected that the unemployment rate for this country will reach 33.5 per cent by 2020 (World Bank, 2018), with consequences that are better imagined, if the trend is not urgently reversed.

It is a thing of joy to note that Nigeria has not been resting on her oars over the years in terms of dedicated efforts to curb the unemployment problem. Various government social intervention programmes targeted at reducing youth unemployment and eradicating poverty have been implemented by different administrations since Nigeria gained independence. Available records showed that from 1972 to date, about 14 different programmes have been implemented. These programmes included the National Accelerated Food Production Programme (NAFPP), implemented between 1972 and 1973. Others were the current National Social Investment Programme (NSIP) which has been ongoing since 2017, embedded in the National Economic Recovery and Growth Plan (ERGP) 2017-2020.However; the unemployment rate and poverty levels are on steady paths of growth, indicating high resilience against all the intervention efforts.

No doubt; Nigeria is seating on a gun powder ready for explosion, if the reality of frustration and hopelessness among the vast of Nigerian youths are anything to go by. There is need for the government to create atmosphere favourable for the youth to achieve their desire objectives. The agonies of Boko Haram, Militancy, armed Robberies, Scams and other social deviance are the product of lack of guardianship and vision for national development. Therefore, Investing in youth development is the cornerstone of country's future because of the direct relationship between youthful mindset and developmental aspiration of any society.

\section{Conclusion}

From all indications, youths are catalyst to developmental aspiration of any society.

It is obvious from the above analysis that no country should abandon their youths for whatever reasons. The task of youth development should therefore be paramount to government at all levels, parents, NGO, multinational companies, international donors and all stakeholders in youth development programme. This is to forestall the low level of development that pervading the country resulting from incessant killing, kidnapping and insecurity that are currently rocking Nigeria system.

\section{Recommendation}

From the above analysis, there is direct relationship between youthful mindset and developmental aspiration of any society. To this ends, the following are hereby recommended to ameliorate the situation:

There is the need for government at all levels to embark on policy of youths inclusion in all national agenda because youths are the engine of growth and development since they provide the labour force for production of goods and service.

Moreover, government must play its constitutional role by creating enabling socio-economic and political environment including the provision of Infrastructure to make industrial climate investment friendly. This will encourage investors to invest and thereby create jobs in order to absorb the youths.

Furthermore, there is the need to reinvigorate and overhaul the entire educational system at all levels to create room for entrepreneurial education. So, the Nigerian tertiary education graduates will become job creators and encourage national development.

Finally, government must not relent in the crusade against all forms of corruption in public and private lives in Nigeria. People including Nigerian youths must be made to feel the positive impact of government in their lives. The situation whereby only a few privileged persons in position of authority benefit from the system at the expense of the impoverished masses portends a great and real danger that may incur the wrath of the youths in Nigeria if not urgently addressed.

\section{References}

i. Adebayo, A. (1999). Youth Unemployment and National Directorate of Employment Self-Employment Programmes. Nigeria Journal of Economics and Social Studies, 41 (1), 81-102.

ii. Akintoye, A. (1999). Zango-kataf crises: A case study in otite. Ibadan; Albert formation, Spectrum books.

iii. Alanana, O. O. (2003). Youth Unemployment in Nigeria: Some Implications for the Third Millennium. Global Journal of Social Science, 2 (1), 21-26

iv. Albert, O. (1999) New Direction in the in the Management of Community Conflict. Spectrum Books Ltd. Ibadan, Nigeria pp1-32 
v. Asamu, F. (2006). Ethnic Militias and National Security in J.F. Hassan S. Ebele, A (Ed.), Democracy and Development in Nigeria, Social issues and external relation (Vol. 3)

vi. Awogbenle, A. C. \& Iwuamadi, K. C. (2010). Youth Unemployment: Entrepreneurship Development Programme as an Intervention Mechanism. African Journal of Business Management, 4 (6), 831- 835

vii. Ayinde, O. E. (2008). Empirical Analysis of Agricultural Growth and Unemployment in Nigeria. African Journal of Agricultural Research, 3(7), 465-468.

viii. Boko, S. (1994). Traditional Institutions and Religions Crisis in Northern Nigeria. Journal of Political Science vol. 7 pp 85-96.

ix. Echebiri, R. N. (2008). Characteristics and Determinants of Urban Youth Unemployment in Umuahia, Nigeria: Implications for Rural Development and Alternative Labor Market Variables. A Paper Presented at the ISSER/Cornell/World Bank Conference on 'Shared Growth in Africa' held in Accra, Ghana, July 21-22.

x. Elegbeleye, O. S. (2005). Recreational Facilities in Schools: A Panacea for Youth's Restiveness. Journal of Human Ecology 18(2), 93-98

xi. Federal Govt. of Nigeria (2001): National Youth Policy Available: http://www.thepresidencygov.za/docs/policy/national youth policy.pdf

xii. Gibb, A. A. \& George, M. (1990). The Design of Extension and Related Support Services for Small-Scale Enterprise Development. International Small Business Development Journal, 8 (3), 10-12.

xiii. Haruna, A. and Jumba, H. (2011). Politics of thuggery and patronage in the North Eastern Nigeria. Journal of Academic Reseach International, 1(1), 111-119.

xiv. Herskovits, J. (2012). In Sule, B.(ed), Popular participation and democratization in Nigeria under youth Republic, ARADA.

xv. Imomoh, (2002). Youth Restiveness and Violence in Nigeria. www.medwell journal.com. National Bureau of statistics. (2009). Social Statistics in Nigeria. Abuja: The NBS Publication.

xvi. National Bureau of statistics. (2010). Statistical News: Labor Force Statistics No. 476. Abuja: The NBS Publication.

xvii. National Population commission and ICF Macro. (2009). Nigeria Demographic and Health Survey 2008. Abuja, Nigeria: National Population Commission and ICF Macro.

xviii. Okafor, E. E. (2005) Executive Corruption in Nigeria: A Critical Overview of its Socio-Economic Implications for Development. African Journal for Psychological Study of Social Issues, 8 (1), 21-41

xix. Okafor, E. E. (2007) Technological and Industrial Development in Transitional Societies: Some Lessons from the Failed Projects in Nigeria. Journal of Tribes and Tribals, 5(2), 121-131

xx. Okafor, E. E. (2007) 'Sociological Implications of Communal and Ethno-Religious Clashes in New Democratic Nigeria'Journal of Tribes and Tribals, 5(1), 35-45.

xxi. Onah, F. O. (2001). Unemployment Situation in Nigeria. In E. O. Ezeani and N. N. Elekwa (Eds), Issues inUrbanization and Urban Administration in Nigeria (pp. 154-167). Enugu: Jamo Enterprises.

xxii. Onyekpe, N. (2007). Managing Youth at Election. The Constitution: a Journal of Constitutional Development 7(1):7687

xxiii. Shedrack, G. et al (1999). Coomunnal Conflicts and the Possibilities of Conflict in Wukari Local Government. Taraba State in Community Conflicts in Nigeria Management, Resolution and Transformation, Spectrum Books Ltd, Ibadan, Nigeria pp. 82-117.

xxiv. World Bank. (1998). 1998 World Development Indicators. Washington, D.C.: World Bank. World Bank, (2005). Country Partnership Strategy for the Federal Republic of Nigeria (2005-2009): World Bank Report, Number 32412NG, June 2005 